\begin{tabular}{c} 
International Journal of Engineering \& Technology, $7(4)(2018) 4651-4653$ \\
International Journal of Engineering \& Technology \\
SPC \\
Website: $\begin{array}{c}\text { www. sciencepubco.com/index.php/IJET } \\
\text { doi: } 10.14419 / \text { ijet. } v 7 i 4.9783 \\
\text { Research paper }\end{array}$ \\
\hline
\end{tabular}

\title{
Evaluation of the stressed deformed state of paint and varnish coatings of cement concretes depending on the quality of appearance
}

\author{
Loganina V. I. ${ }^{1 *}$, Skachkov Yu. P. ${ }^{1}$, Demyanova V. S. ${ }^{1}$ \\ ${ }^{1}$ Penza State University of Architecture and Construction, Quality Management and Construction Technologies Affiliation of the first \\ author \\ *Corresponding author E-mail: loganin@mail.ru
}

\begin{abstract}
Information on the application of holography for the evaluation of the stress-strain state of paint coatings is given. It is shown, that the concentration of stresses is observed in the places of inclusions, ripples, streaks, shagreen. At these points a disturbance in the interference pattern is observed. It is revealed, that a more stressed state occurs in coatings with a higher roughness. This contributes to the early destruction of the coating during operation. It was found, that there is a proportional relationship between the initial roughness of the coating and the probability of its destruction. The results of studies of the resistance of coatings are presented depending on the quality of the appearance of the surface.
\end{abstract}

Keywords: Coatings; Holography; Stress-Strain State; Cracking; Resistance.

\section{Introduction}

At present, the coatings appearance quality is estimated by class in accordance with GOST 9. 407-74 "Unified system of corrosion and aging. Paint coatings. Groups, technical requirements and marking", taking into consideration the number of inclusions and the distance between them, the presence of shagreen, water stains, waviness, etc. Seven classes of coatings appearance quality on a metal substrate are identified. In the paper [1 - 3] it is proposed to evaluate the appearance quality of cement concrete protective and decorative coatings as IV-VII classes. According to the theory of strength of solids the probability of coatings failure is determined by the defects presence and concentration, including those on the surface coatings. Consequently, the appearance quality of protective and decorative coatings determines their state of stress and stability during the service. The currently available methods of experimental study of the stress-strain state (SSS) of structures are reduced to a direct measurement of deformations in the test article. Stresses are determined indirectly through deformations. The holographic methods are known to be used for a non-destructive testing. The key point of the holographic non-destructive testing is that the fault isolation is determined by the pattern abnormality of the interference fringes [4 - 6]. Interferograms are typically obtained by double exposure team by comparing two states of the sample surface before and after the impact or loading. The internal defects are detected by the pattern of fringes if they cause enough disturbance of the displacement field, and thus of the interference pattern observed on the sample surface. The purpose of the work - to assess the influence of the quality of the appearance of the paint coatings of cement concretes on their durability during operation

\section{The research methods}

The object of the research were two painted samples of cement-sand matrix $4 \times 4 \times 16 \mathrm{sm}$ in size with different void content. The technology of obtaining holograms was as follows. The samples were placed in a box. In the vicinity of the coating surface a high-resolution Plate PFG-03M sensitized to the red spectrum of the laser was rigidly fixed. To register holograms in colliding beams at a certain distance from the samples a semiconductor laser on the red line (the laser wavelength $\lambda=0,65 \mathrm{mk}$ ) was used. The laser has a sufficient coherence for recording holograms (Fig 1).

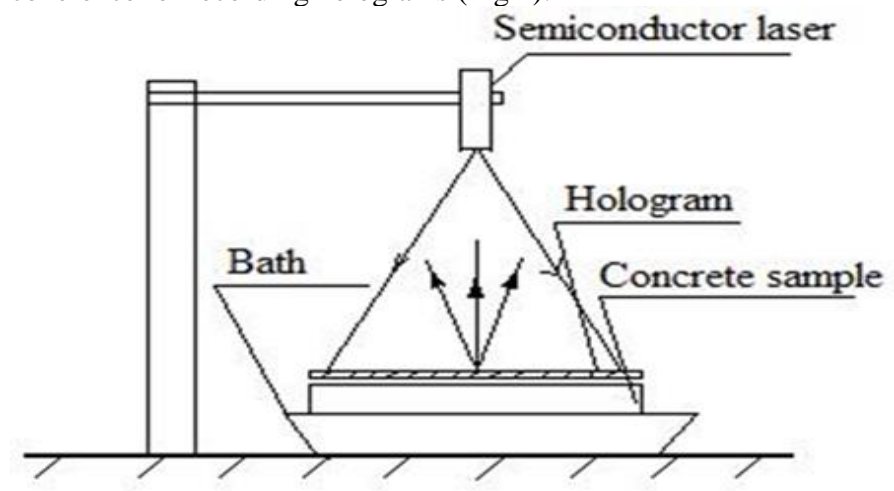

Fig. 1: Optical scheme of registration of holograms.

Totally we have performed 50 measurements on each surface on scheme (Fig. 2.). At the initial stage we made the first exposure, and then we added water to the box $2 / 3$ of the height of the mortar sample. In a certain period of time after the sample had been saturated with moisture, the second exposure was made, and then photoplates 
were photoprocessed with GP-3 developer, recommended by the manufacturer of the plates (without fixing) and then it was washed with distilled water

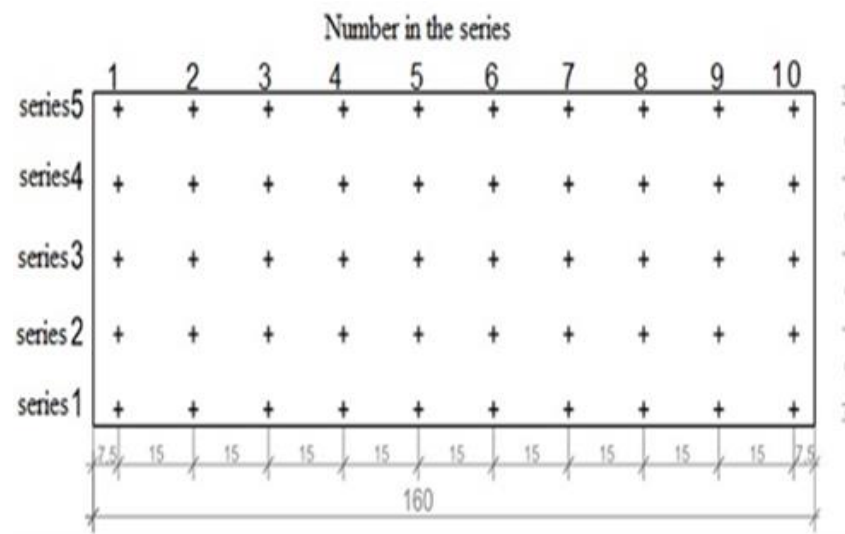

Fig. 2: Scheme of the measurement of surface roughness paint coatings on cement substrate (all dimensions in $\mathrm{mm}$ ).

\section{The results of research}

Analysis of the experimental data indicates that there is a correlation between the roughness index of the coating surface and its stress-strain state (SSS). For example, at roughness of the paint coating on the basis of MA-15 paint on a substrate with a porosity of $24 \%$, equal to $\mathrm{Ra}=4-6 \mu \mathrm{m}$ (Fig. 3), is observed a disturbance of the order and the curvature of the bandson the interferogram in the area of the paint coating B3-A3-A4-B4 a. It indicates the presence in this area of possible defective internal fracture and local stress concentration.

a)

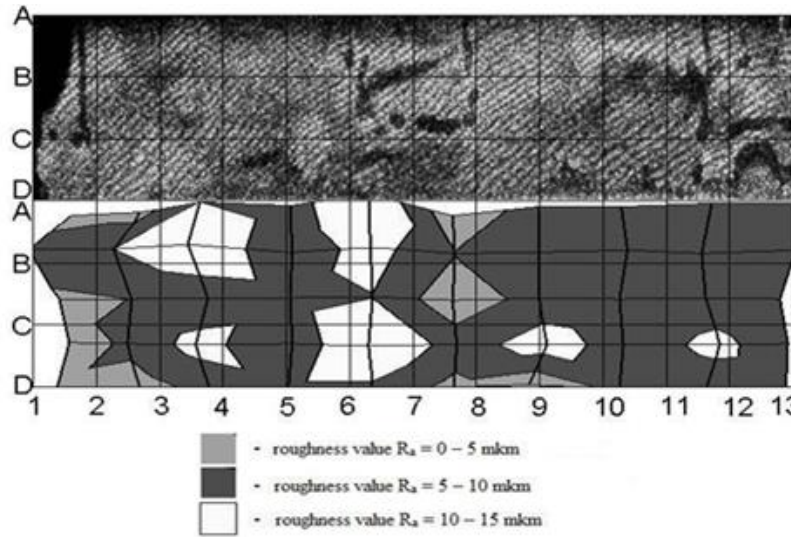

Fig. 3: Interferogram of the paint coating based on paint MA-15, the porosity of the substrate $24 \%$ (A), the distribution of roughness over the surface of the coating (B).

In the D3-C3-C4-D4 and C4-D4-C5-D5 regions, the roughness of the coating is $8-12 \mu \mathrm{m}$ and also a disturbance the order of the bands is observed in this region. Similar disturbances of the interference pattern are also observed in the regions D9-C9-C10-D10 and D11C12-C12-D11, in which the roughness of the coating is $10-15 \mu \mathrm{m}$. These regions were separately isolated and are shown in Fig. 4. In the region of D3-C3-C4-D4 (Fig. 4), characterized by a low roughness value $(0-2 \mu \mathrm{m})$, a more even distribution of the interference fringes is observed. It indicates a uniform stress-strain state of the coating in this zone.

In the regions of D8-C8-C9-D9 and D9-C9-C10-D10 (Fig. 5), the roughness is $5-10 \mu \mathrm{m}$. There is a distortion of the pattern of bands and a violation of the order of the bands is observed. A similar pattern is also characteristic for the $\mathrm{C} 8-\mathrm{B} 8-\mathrm{B} 9-\mathrm{C} 9$ region.

\section{The paper should have the following struc- ture}

a)
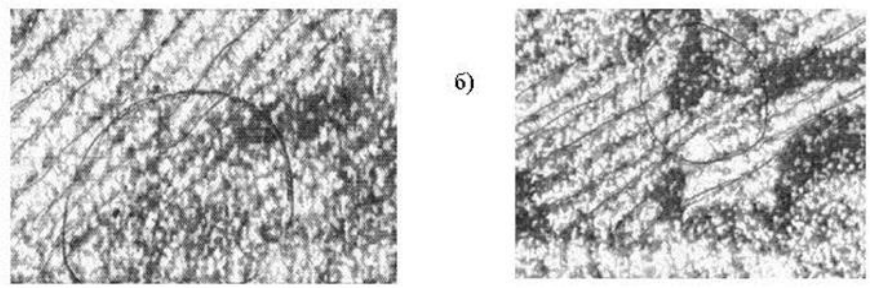

в)

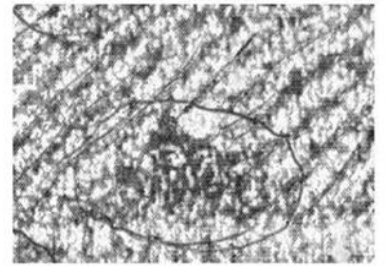

Fig. 4: Zones of order violation and distortion of the interference pattern of the Bands: A) D3-C3-C4-D4 And C4-D4-C5-D5, B) D11-C12-C12-D11, C) D9-C9-C10-D10 (MA- 15 with a dynamic viscosity 26.0 Pa. s, a substrate porosity $24 \%$ ).

a)
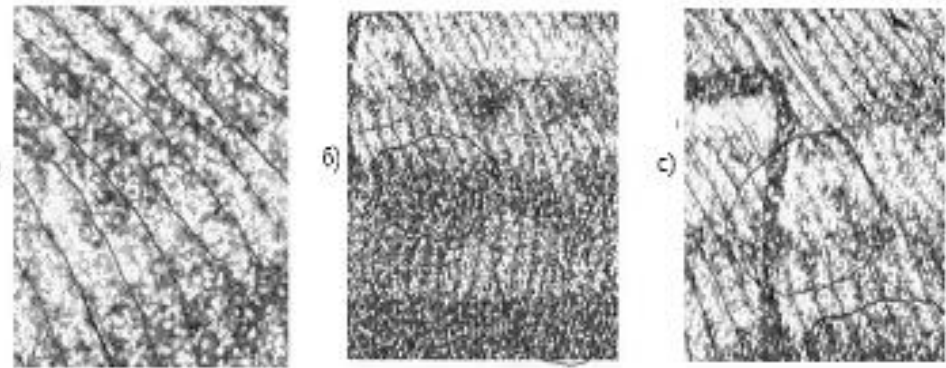

Fig. 5: A) Zone of uniform distribution of the Bands D3-C3-C4-D4 (paint MA-15, dynamic viscosity $26.0 \mathrm{~Pa}$. s., porosity of the substrate $32 \%$ ) B) D8C8-C9-D9 and D9-C9-C10-D10, C) C8-B8-B9-C9 (paint surface MA-15, dynamic viscosity 26.0 Pa.s, porosity of the substrate $32 \%$ ).

More tense state of the coating in places of greater roughness promotes to destroy the coating in these places during operation. It is established that in the process of cyclic freezing-thawing the cracks appear locally and are formed near defects on the surface of the coatingIn particular, surface cracks visible to the naked eye appeared on the paint coating MA-15, characterized by a roughness index $\mathrm{Ra}>3 \mu \mathrm{m}$, after 10 cycles of freeze-thaw, and on a coating with a roughness index Ra $<3 \mu \mathrm{m}$ - after 15 test cycles. Similar patterns are also characteristic for other coatings (Table 1).

Similar patterns are obtained when tested in alternate humidification-drying. Dynamics of fracture coatings in the process of wetting and drying are shown in Table.2.

The results (Table. 2) suggest, that there is a proportional relationship between the original roughness of the coating and the likelihood of its destruction. So, the probability of failure of the coating based on latex paint with an initial roughness $\mathrm{Ra}=2,55 \mu \mathrm{m}$ after 5 test cycles, $34.3 \%$, and coverage with the original roughness $\mathrm{Ra}$ $=3,29 \mu \mathrm{m}-36,8 \%$.

Fig. 6 shows interferogram of coatings based on paints MA-15, applied by brush on substrate with porosity $28 \%$ and with a dynamic viscosity of $\eta=26.0$ Pas after 60 days of humidification. On the interference pattern (Fig. 4), traced the complex space move and the crack opening displacement and high stress concentration near the cracks, resulting in the formation of initiation zones of plastic deformation []. The initial roughness of the coating was (to moisturize) $\mathrm{Ra}=4,3 \mu \mathrm{m}$, and after 60 days moisture $-6,87 \mu \mathrm{m}$. During aging the number of defects increased $10 \%$. At with further humidification of the coating in the places of stress concentration (distortion of the pattern of interference fringes, on the interferogram) cracks 
and peeling paint. A fragment of the coating with a crack, which appeared after 70 days of humidification, are presented in Fig. 7.

Table 1: The Change in the Quality of the Appearance of coatings in the

\begin{tabular}{|c|c|c|c|c|c|c|}
\hline \multirow{2}{*}{$\begin{array}{l}\text { Name of } \\
\text { paint }\end{array}$} & \multirow{2}{*}{$\begin{array}{l}\text { The } \\
\text { sur- } \\
\text { face } \\
\text { rough } \\
\text { ness, } \\
\text { Ra, } \\
\mu \mathrm{m}\end{array}$} & \multirow{2}{*}{$\begin{array}{l}\text { The } \\
\text { num } \\
\text { ber } \\
\text { of } \\
\text { de- } \\
\text { fects } \\
\text { after } \\
\text { cur- } \\
\text { ing }\end{array}$} & \multicolumn{4}{|c|}{$\begin{array}{l}\text { The number of defects / probabilities of } \\
\text { fracture coatings, } \% \\
\text { The test cycles }\end{array}$} \\
\hline & & & 5 & 10 & 13 & 15 \\
\hline \multirow{4}{*}{$\begin{array}{l}\text { Alkyd } \\
\text { enamel } \\
\text { PF-115 }\end{array}$} & 2,78 & 18 & $25 / 35,5$ & $31 / 40,7$ & $\begin{array}{l}56 / 47, \\
2\end{array}$ & $\begin{array}{l}57 / 53, \\
8\end{array}$ \\
\hline & 3,7 & 29 & $38 / 31,0$ & $\begin{array}{l}56 / 100 \\
*\end{array}$ & - & - \\
\hline & 5,1 & 35 & $43 / 32,4$ & $\begin{array}{l}\text { 77/100 } \\
*\end{array}$ & - & - \\
\hline & 5,6 & 54 & $67 / 33,4$ & $\begin{array}{l}80 / 100 \\
*\end{array}$ & - & - \\
\hline \multirow{5}{*}{$\begin{array}{l}\text { Oil paint } \\
\text { MA-15 }\end{array}$} & 2,14 & 10 & $15 / 34,0$ & $20 / 35,2$ & $\begin{array}{l}21 / 39 \\
2\end{array}$ & $\begin{array}{l}26 / 40, \\
8\end{array}$ \\
\hline & 2,18 & 20 & $23 / 35,1$ & $26 / 38,1$ & $\begin{array}{l}30 / 40, \\
0\end{array}$ & $\begin{array}{l}33 / 41, \\
3\end{array}$ \\
\hline & 3,3 & 29 & $\begin{array}{l}60 / 100 \\
*\end{array}$ & - & - & - \\
\hline & 5,6 & 30 & $\begin{array}{l}72 / 100 \\
*\end{array}$ & - & - & - \\
\hline & 8,0 & 25,6 & $\begin{array}{l}82 / 100 \\
*\end{array}$ & - & - & - \\
\hline \multirow{4}{*}{$\begin{array}{l}\text { Aqueous } \\
\text { disper- } \\
\text { sion } \\
\text { (facade) }\end{array}$} & 2,4 & 40 & $44 / 39,6$ & $47 / 45,8$ & $\begin{array}{l}56 / 46 \\
8\end{array}$ & $\begin{array}{l}64 / 48, \\
2\end{array}$ \\
\hline & 2,7 & 55 & $61 / 42,8$ & $64 / 47,2$ & $\begin{array}{l}68 / 47, \\
9\end{array}$ & $\begin{array}{l}71 / 49, \\
3\end{array}$ \\
\hline & 3,4 & 56 & $67 / 43,2$ & 70/47,6 & $\begin{array}{l}74 / 48, \\
0\end{array}$ & $\begin{array}{l}77 / 49, \\
8\end{array}$ \\
\hline & 4,4 & 60 & $69 / 45,1$ & $72 / 48,7$ & $\begin{array}{l}83 / 49, \\
0 \\
\end{array}$ & $\begin{array}{l}91 / 51, \\
8\end{array}$ \\
\hline
\end{tabular}

Note: $*$ - there is a peeling of coating.

Table 2: The Change in the quality of appearance of coating in the process

\begin{tabular}{|c|c|c|c|c|c|c|c|}
\hline \multirow{2}{*}{$\begin{array}{l}\text { Name } \\
\text { of } \\
\text { paint }\end{array}$} & \multirow{2}{*}{$\begin{array}{l}\text { The } \\
\text { surface } \\
\text { rough- } \\
\text { ness, } \\
\text { Ra, mi- } \\
\text { crons }\end{array}$} & \multirow{2}{*}{$\begin{array}{l}\text { The } \\
\text { num- } \\
\text { ber } \\
\text { of } \\
\text { de- } \\
\text { fects } \\
\text { after } \\
\text { cur- } \\
\text { ing }\end{array}$} & \multicolumn{5}{|c|}{$\begin{array}{l}\text { The number of defects / probabilities of } \\
\text { fracture coatings, } \% \\
\text { The test cycles }\end{array}$} \\
\hline & & & 5 & 8 & 11 & 13 & 15 \\
\hline \multirow{4}{*}{$\begin{array}{l}\text { Alkyd } \\
\text { enamel } \\
\text { PF- } \\
115\end{array}$} & 3,2 & 31 & $\begin{array}{l}36 / 4 \\
8,2\end{array}$ & $\begin{array}{l}42 / 57 \\
, 6\end{array}$ & $\begin{array}{l}50 / 58 \\
, 3\end{array}$ & $\begin{array}{l}59 / 10 \\
0^{*}\end{array}$ & - \\
\hline & 4,0 & 32 & $\begin{array}{l}37 / 4 \\
8,8\end{array}$ & $\begin{array}{l}47 / 10 \\
0 *\end{array}$ & - & - & - \\
\hline & 5,8 & 39 & $\begin{array}{l}48 / 4 \\
9,7\end{array}$ & $\begin{array}{l}59 / 10 \\
0^{*}\end{array}$ & - & - & - \\
\hline & 6,2 & 44 & $\begin{array}{l}59 / 5 \\
0,2\end{array}$ & $\begin{array}{l}60 / 10 \\
0 *\end{array}$ & - & - & - \\
\hline \multirow{3}{*}{$\begin{array}{l}\text { Oil } \\
\text { paint } \\
\text { MA- } \\
15\end{array}$} & 4,6 & 13 & $\begin{array}{l}16 / 4 \\
3,9\end{array}$ & $\begin{array}{l}24 / 50 \\
, 6\end{array}$ & $\begin{array}{l}34 / 10 \\
0^{*}\end{array}$ & - & - \\
\hline & 6,9 & 22 & $\begin{array}{l}28 / 4 \\
4,8\end{array}$ & $\begin{array}{l}37 / 10 \\
0^{*}\end{array}$ & - & - & - \\
\hline & 9,1 & 33 & $\begin{array}{l}54 / 4 \\
6,3\end{array}$ & $/ 100^{*}$ & - & - & - \\
\hline $\begin{array}{l}\text { Aque- } \\
\text { ous }\end{array}$ & 2,55 & 50 & $\begin{array}{l}60 / 3 \\
4,3\end{array}$ & $\begin{array}{l}64 / 36 \\
, 8\end{array}$ & $\begin{array}{l}67 / 39 \\
, 8\end{array}$ & $\begin{array}{l}70 / 44 \\
, 0\end{array}$ & $\begin{array}{l}72 / 4 \\
6,8\end{array}$ \\
\hline $\begin{array}{l}\text { disper- } \\
\text { sion }\end{array}$ & 3,07 & 62 & 136,2 & $\begin{array}{l}73 / 39 \\
, 2\end{array}$ & $\begin{array}{l}81 / 42 \\
, 3\end{array}$ & $\begin{array}{l}89 / 45 \\
, 7\end{array}$ & $\begin{array}{l}95 / 4 \\
8,3\end{array}$ \\
\hline $\begin{array}{l}\text { (facad } \\
\text { e) }\end{array}$ & 3,29 & 68 & $\begin{array}{l}73 / 3 \\
6,8 \\
\end{array}$ & 139,6 & $\begin{array}{l}86 / 42 \\
, 6\end{array}$ & $\begin{array}{l}92 / 46 \\
, 3\end{array}$ & $\begin{array}{l}98 / 4 \\
8,7\end{array}$ \\
\hline
\end{tabular}

Note: $*$ - there is a peeling of coating.

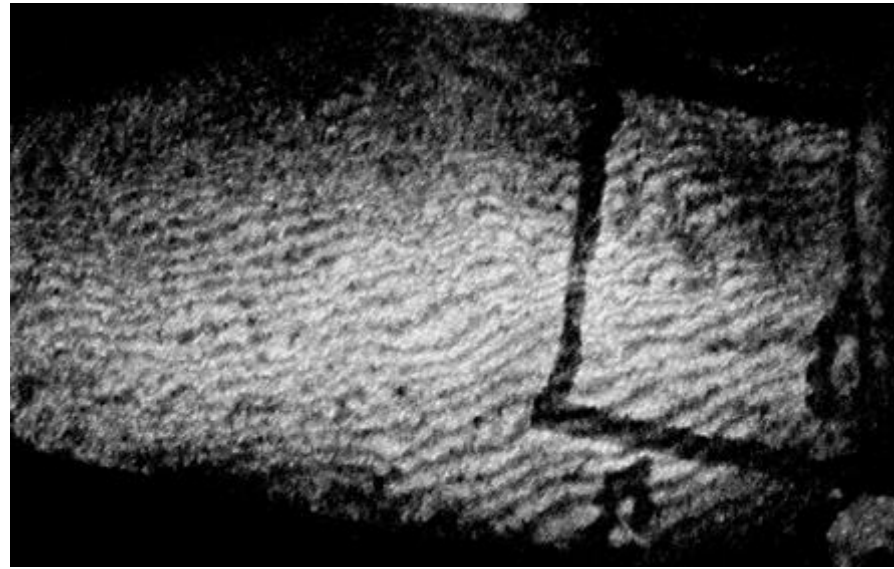

Fig. 6: Interferogram coating based on paints MA-15 after 60 days of humidification (dynamic viscosity of 26.0 Pas., porosity of substrate $28 \%$ ).

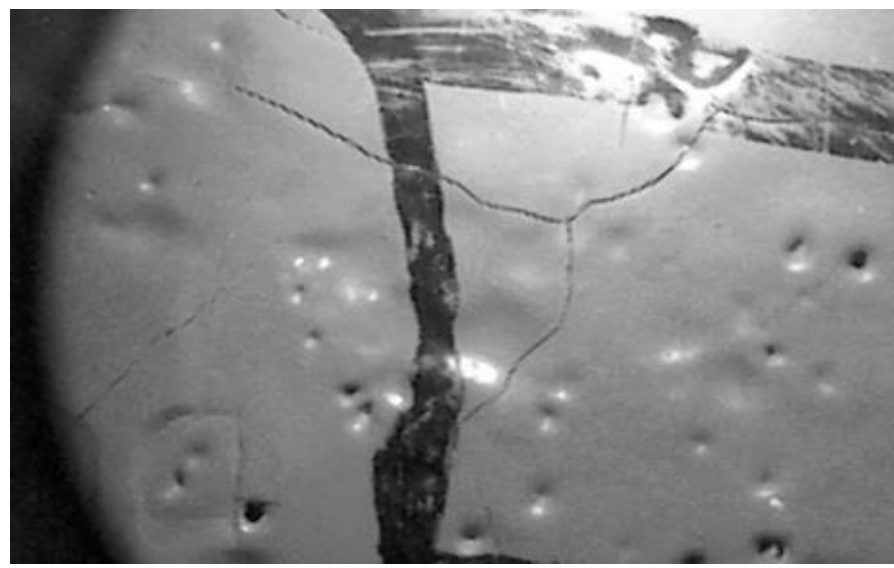

Fig. 7: A Crack in the coating based on paint MA15 after 70 days of humidification (dynamic viscosity of 26.0 Pas, porosity of substrate $28 \%$ ).

\section{Conclusions}

The results of studies convincingly indicate a relation of stressstrain state and resistance of coatings with the quality of their appearance. This creates the possibility to control the lifetime of coatings, by adjusting the rheological properties of paints, the degree of surface preparation to be coated, etc.

\section{References}

[1] Orentlicher L.P., Loganina V.I., Protective decorative coatings for concrete and stone buildings. Study guide, Moscow, Stroyizdat, (1992).

[2] V. I. Loganina, "The Influence of Surface Quality of Coatings on Their Deformation Properties", Contemporary Engineering Sciences, Vol. 7, no. 36, (2014), pp. 1935-1941. HIKARI Ltd, www. m-hikari. com http://dx. doi. org/10. 12988/ces. 2014. 411241.

[3] Loganina V.I., "Maintenance of Quality of Paint and Varnish Coverings of Building Products and Designs", Contemporary Engineering Sciences, Vol. 7, no. 36, (2014), pp. 1943-1947. HIKARI Ltd, www. m-hikari. com http://dx. doi. org/10. 12988/ces. 2014. 411243.

[4] Volkov I.V., Construction surface deformation determination. Invention certificate №1269635 dated 08. 07. 1986.

[5] Holographic non-desructive research. Translated from English under editorship of R. K. Erf, V. A. Karasyov, Moscow, Mashinostroyeniye, (1979), pp.448.

[6] Loganina V.I., Skachkov Yu.P., "The application of the holographic Method for Evaluation of a stress deformation state of cement paint coatings", International Journal of Applied Engineering Research, Vol. 11, Number 14 (2016), pp 8377-8378, http://www.ripublication.com. 